\title{
Determinants of Postpartum Blues for Postpartum Mothers Survey Study at the Madiun City General Hospital
}

\author{
Tinuk Esti Handayani*, Budi Joko Santosa, Suparji Suparji, Patrisia Anastasia Setyasih \\ Department of Midwifery, Politeknik Kesehatan Kementerian Kesehatan Surabaya, Surabaya, Indonesia
}

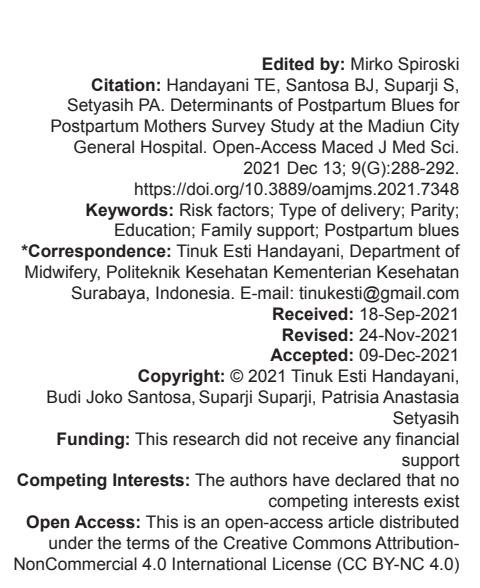

\section{Introduction}

Postpartum is a period marked by a heavy burden on the mother, especially disturbances in affective abilities [1]. After the birth process, the mother will experience physical and psychological changes. Although changes in the mother are usually seen as a positive experience for a woman, physical, psychological, and social adaptations are not easy [2]. Psychological disorders after childbirth can be mildly called baby blues. The failure of a woman to make psychological adaptations during this period can cause postpartum blues. A further impact of the incidence of postpartum blues is postpartum depression and postpartum psychosis.

The incidence of postpartum blues in Indonesia ranges from $50 \%$ to $70 \%$ in postpartum women. The results of the Oktaputrining study in the Madiun Regency area stated that $51 \%$ of respondents were experiencing postpartum blues [3]. Another opinion says that mood disorders are common in women up to $85 \%$ during the postpartum period, although only $10-15 \%$ of mothers experience significant clinical symptoms [1]. Research in Sukoharjo Regency shows that the prevalence of postpartum depression is $18.5 \%$ [4].
Postpartum blues are caused by several factors such as internal factors, including hormone levels, age, physical condition, unplanned pregnancy, type of delivery, and mother's experience. In addition, it is also caused by external factors, including socioeconomic, education, work, and family support [4], [5]. A further impact of postnatal maternal psychological disorders that are not correctly intervened is psychological disorders for the mother and her baby. Postpartum blues will cause less interest in the baby, unable to recognize the baby's needs, often cry, irritable, lose self-confidence, can lead to postpartum depression and psychosis. In addition, the impact of the postpartum blues that are not handled will result in the baby not getting exclusive breastfeeding so that growth and development are disrupted, then behavioral problems and emotional problems will occur [6].

Efforts to reduce the incidence of postpartum blues can be made by improving the quality of services in health-care facilities such as hospitals, maternal clinics, and community health centers. The services provided include detecting postpartum blues symptoms in postpartum mothers so that prevention and treatment can be carried out appropriately [7]. 


\section{Methods}

A cross-sectional study design, the population is all postpartum mothers at the Madiun City Hospital in March-April 2020, the population is 52 respondents. The sample size is 47 people, sampling using the simple random sampling technique. The independent variables were age, type of delivery, parity, education, and family support. The dependent variable is postpartum blues symptoms. The research instrument used a questionnaire and a checklist data analysis using Chisquare and Fisher's exact test with a significance level of $=0.05$.

\section{Results}

\section{Research result data characteristics of respondents}

The results of research Table 1 present data about the description of the characteristics of the respondents consisting of data on the type of delivery, parity, and level of education. The study results on the description of the characteristics of respondents are based on the type of delivery in mothers who were treated at the Madiun public hospital, $65 \%$ of 47 mothers were treated with the background of childbirth with action. The background parity rate of the mothers who were treated was $74.5 \%$ multiparous mothers or mothers with a history of more than 2 times having experienced childbirth. The study results on the level of mother's education of 47 mothers who were treated at the hospital $63 \%$ of mothers had a basic education level background.

Table 1: Frequency distribution of respondent characteristics by type of delivery, parity level, and education level

\begin{tabular}{lll}
\hline Variable & Frequency (f) & Percentage \\
\hline Type of delivery & & \\
CCCC & 30 & 63.8 \\
Normal & 17 & 36.2 \\
$\quad$ Total & 47 & 100.0 \\
Parity & & \\
$\quad$ Primipara & 12 & 25.5 \\
$\quad$ Multipara & 35 & 74.5 \\
$\quad$ Total & 47 & 100 \\
Education & & \\
Base & 4 & 8.5 \\
Intermediate & 30 & 63.8 \\
Higher education & 13 & 27.7 \\
Total & 47 & 100.0 \\
\hline
\end{tabular}

\section{Research results data level of family support and symptoms of postpartum blues}

Table 2 describes the level of family support and symptoms of postpartum blues that occur in mothers who are treated at the Madiun City General Hospital. The data representing the level of family support are categorized into three categories, namely, high, sufficient, and less support. The level of family support in the sufficient category reaches $20 \%$. The description of postpartum blues symptoms that occur in postpartum mothers during treatment is mothers who experience symptoms as many as 11 people, around $23.4 \%$.

Table 2: Frequency distribution of family support levels and symptoms of postpartum blues

\begin{tabular}{lll}
\hline Variable & Frequency (f) & Percentage \\
\hline Family support & & \\
$\quad$ Not enough & 9 & 19.1 \\
Enough & 20 & 42.6 \\
$\quad$ Tall & 18 & 38.3 \\
$\quad$ Total & 47 & 100 \\
Symptoms of postpartum blues & & \\
$\quad$ There are & 11 & 23.4 \\
$\quad$ symptoms & & 76.6 \\
$\quad$ No symptoms & 36 & 100 \\
$\quad$ Total & 47 & \\
\hline
\end{tabular}

\section{Relationship of age, type of delivery, parity, and level of family support for postpartum mothers with postpartum blues symptoms}

The description of the study results in Table 2, from several factors, and the incidence of postpartum blues in postpartum mothers who are treated at the Madiun City public hospital are as follows: Factors in the age group at risk for presenting the incidence of postpartum blues were more significant $(60 \%)$ than the maternal age group at risk. The description of the incidence of postpartum blues from the type of delivery factor, the higher percentage is delivery with action, which reaches $33.3 \%$. The incidence of postpartum blues based on parity shows that primiparous mothers show a higher percentage than multiparous mothers. The factor of maternal education at a low level of education describes the highest percentage of postpartum blues in mothers who are treated at the Madiun City General Hospital compared to the level of secondary education and higher education.

The results of the study in Table 2 are based on the results of the Fisher's exact test statistical test, the factors that contributed to the incidence of postpartum blues in postpartum mothers were maternal age, $p$ $=0.006(p<0.05)$. The type of labor factor with $p=$ $0.032(p<0.05)$ and parity factor with action, $p=0.033$ $(p<0.05)$. Another factor related to the incidence of postpartum blues is the education factor with $p=0.006$ $(p<0.05)$. The family support factor was also proven to affect the incidence of postpartum blues symptoms with $p=0.000(p<0.05)$.

\section{Discussion}

Postpartum blues are a mild affective disorder syndrome that often appears in the $1^{\text {st }}$ week after delivery, tends to worsen on the $3^{\text {rd }}-5^{\text {th }}$ day, and lasts 
within 14 days or 2 weeks postpartum, characterized by brief crying, feelings of loneliness, or rejection, anxiety, confusion, restlessness tired, forgetful, and unable to sleep. Postpartum blues can be a problem that disrupts the harmony of a married couple, is unpleasant, and causes uncomfortable feelings for mothers who experience it [7].

The result of the analysis of the age factor with the incidence of postpartum blues is $p=0.006(p<0.05)$. It is proven that the age factor affects the incidence of postpartum blues in hospitalized mothers. The results of another study conducted by Fatmawati stated a direct and indirect negative relationship between maternal age and postpartum depression through complications, pregnancy status, and coping strategies, and it was statistically significant [8]. Fatmawati also explained that increasing maternal age would increase emotional maturity and coping in dealing with pregnancy and adaptation after childbirth to increase involvement and satisfaction in the role of parents and form optimal patterns of maternal behavior [6], [8], [9]. Kurniawati said that pregnant adolescents are more at risk of experiencing childbirth complications such as the incidence of anemia, gestational hypertension, and cephalopelvic disproportion and are at risk of giving birth to babies with low birth weight. Young people are also more difficult to accept their pregnancy, so they try to cover up the pregnancy. As a result, mothers do not receive prenatal care before the third trimester [7], [10].

The results of the analysis of the type of labor with the incidence of postpartum blues obtained $p=0.032(p<0.05)$. The factors of type of delivery in this study were labor with operative action or Syntocinon drip action for intervention to increase labor. Zoleykha Asgarlou's study showed that childbirth complications were directly related to postpartum depression and were statistically significant [4], [11]. The results of this study are in line with Mathisen's study, where complications during pregnancy and childbirth were significantly associated with symptoms of postpartum depression. This is similar to the results of a Dutch study of 4941 women, in which preeclampsia, hospitalization, and emergency cesarean section were significantly associated with postpartum depression. In the study, the risk of postpartum depression increased with increasing number of complications. A Japanese study of 627 women found that high EPDS scores were significantly associated with preterm labor and difficult delivery [4], [12], [13].

The results of the parity level factor analysis test (primipara and multipara) were obtained with $p=0.033(p<0.05)$. These results prove that parity factors contribute to the incidence of postpartum blues in hospitalized mothers. The results of Fatmawati's study showed that parity was not directly related to postpartum depression through pregnancy status and delivery complications and was statistically significant [4], [14], [15], [16]. Primiparous women do not have experience caring for children, causing fear and worry when they make mistakes in caring for babies. Likewise, in carrying out their duties as a mother, primiparous women feel confused, more burdened, and feel their freedom is reduced by the presence of a child. Inexperienced mothers will have an impact on the care given to their babies. A mother knowledge also has a major influence on the care given to her child [8]. The large number of children born greatly affects the health of the mother. In the first birth, there is a rather high risk of complications when compared to the second or third birth. The second or third births are generally safer, but in the fourth and subsequent births, the risk of infant and maternal mortality is higher [17]. The IDHS results show that the proportion of unwanted pregnancies increases with the order in which children have been born [9]. Women who have had many children but are still pregnant and the pregnancy was unwanted may be due to contraceptive failure. Mothers who have given birth too many children also feel that the number of existing children has reached the ideal number as desired so that if the mother becomes pregnant again, the possibility of an unwanted pregnancy is greater [18], [19], [20]. Other studies explain that parity is the most dominant factor causing postpartum blues. The occurrence of postpartum blues involves biopsychosocial factors before and after delivery [21].

Based on the statistical test using the Chisquare test between education and postpartum blues symptoms in Table 3 , it is proven that there is a relationship between education and postpartum blues symptoms in postpartum mothers who are treated at the Madiun public hospital. Another study explained that the factor of maternal education level was indirectly related to postpartum depression through coping strategies and was statistically significant [4]. This study was also supported by research from Salonen who said that the level of education had a significant or significant effect on the incidence of postpartum depression of $p=0.0019$ [22]. Indriasari's research shows that the higher the education of the mother, the lower the risk of experiencing postpartum depression. The level of education affects the effectiveness of the coping strategies used [23]. People who are highly educated will be more realistic and more active in solving problems than those with low education. The higher the level of education is expected to be more able to adapt [23], [24], [25].

Several risk factors that are considered to be the trigger for postpartum depression to postpartum depression include hormonal changes, maternal age at delivery, history of childbirth, history of past depression, and social support [26], [27], [28], [29]. The results of the study in Table 3 , show the influence of family support factors on the incidence of postpartum blues obtained is $p=0.000(p<0.05)$. Family support factors have an impact on the incidence of postpartum blues in mothers who are hospitalized. The results of Ryanawati Putriarsih's research based on the analysis 
Table 3: Relationship between age, type of delivery, parity, and level of family support for postpartum mothers with postpartum blues symptoms

\begin{tabular}{|c|c|c|c|c|c|c|}
\hline \multirow[t]{3}{*}{ Variable } & \multicolumn{4}{|c|}{ Symptoms of postpartum blues } & \multirow{2}{*}{\multicolumn{2}{|c|}{ Frequency }} \\
\hline & \multicolumn{2}{|c|}{ There } & \multicolumn{2}{|c|}{ None } & & \\
\hline & $f$ & $\%$ & $f$ & $\%$ & $f$ & $\%$ \\
\hline Age & & & & & & $p=0.008$ \\
\hline At risk & 6 & 60 & 4 & 40 & 10 & 100 \\
\hline No risk & 5 & 13.5 & 32 & 86.5 & 37 & 100 \\
\hline Total & 11 & 23.4 & 36 & 76.6 & 47 & 100 \\
\hline Type of delivery & & & & & & $p=0.076$ \\
\hline Action & 10 & 33.3 & 20 & 66.7 & 30 & 100 \\
\hline Normal & 1 & 5.9 & 16 & 94.1 & 17 & 100 \\
\hline Total & 11 & 23.4 & 36 & 76.6 & 47 & 100 \\
\hline Parity & & & & & & $p=0.033$ \\
\hline Primipara & 6 & 50 & 6 & 50 & 12 & 100 \\
\hline Multipara & 5 & 14.3 & 30 & 85.7 & 35 & 100 \\
\hline Total & 11 & 23.4 & 36 & 76.6 & 47 & 100 \\
\hline Education & & & & & & $p=0.006$ \\
\hline Base & 3 & 75 & 1 & 25 & 4 & 100 \\
\hline Intermediate & 8 & 26.7 & 22 & 73.3 & 30 & 100 \\
\hline Higher education & 0 & 0 & 13 & 100 & 13 & 100 \\
\hline Total & 11 & 23.4 & 36 & 76.6 & 47 & 100 \\
\hline Family support & & & & & & $p=0.000$ \\
\hline Not enough & 8 & 88.9 & 1 & 11.1 & 9 & 100 \\
\hline Enough & 3 & 15 & 17 & 85 & 20 & 100 \\
\hline Tall & 0 & 0 & 18 & 100 & 18 & 100 \\
\hline Total & 11 & 23.4 & 36 & 76.6 & 47 & 100 \\
\hline
\end{tabular}

showed that family support was indirectly related to postpartum depression through pregnancy status and self-efficacy and was statistically significant [4], [27], [28]. The results of this study are in line with Kusumastuti's research which states that husband's support has a significant relationship with the incidence of postpartum depression. This is because the mother feels comfortable because of the support provided by her husband during childbirth until the postpartum period. In addition, it is also due to the self-confidence and self-efficacy that grow with the support of the people around, especially the husband's support so that the mother can go through the puerperium normally [4], [30]. Another opinion is that husbands support for mothers leads to an increase in the quality of life and mental health. Thus, unwanted pregnancy due to low levels of husband support is a risk factor for postpartum depression [31].

Susanti explained that post-delivery mothers showed symptoms of the postpartum blues because they were triggered by the additional economic burden on the family after giving birth, a long labor process that had never been experienced before, feeling uncomfortable with health care workers, physical exhaustion, a perceived lack of support from the family, or an unfavorable physical environment support. The variables that provide the greatest predictions of the postpartum blues sequentially are self-adjustment, stress coping, and social support [7]. According to Iskandar quoted by Mariyatul, postpartum blues occur due to a lack of support for the adjustments needed by a woman in facing her new role as a mother [32], [33]. Based on the study results, it can be concluded that postpartum 1-10 days at BPM NanikCholid Surabaya are mostly primipara, postpartum aged 1-10 days at BPM NanikCholid Surabaya are mostly experienced maternity blues. There is a relationship between parity and the occurrence of maternity blues on the $1-10^{\text {th }}$ postpartum day at BPM NanikCholid Surabaya [34], [35].

\section{Conclusion}

The research conclusion shows that the factors that influence the emergence of postpartum blues symptoms in postpartum mothers include age, type of delivery, childbirth experience (parity), education, and level of family support. The type of labor and delivery experience (parity) had a less significant effect on postpartum blues symptoms. While the factors that have a significant effect on the incidence of postpartum blues symptoms are age, education and family support.

Suggestions from the results of this study are labor penology officers are expected to be able to detect early postpartum blues events so that appropriate actions can be taken according to the conditions and needs of the mother. It is necessary to improve the quality of services in health-care facilities such as hospitals, maternity clinics, and community health centers. The services provided include counseling and detecting postpartum blues symptoms in postpartum mothers so that prevention and treatment can be carried out appropriately.

\section{Ethical considerations}

The authors have completely observed ethical issues (including plagiarism, informed consent, misconduct, data fabrication and/or falsification, double publication and/or submission, and redundancy).

\section{References}

1. Sylvén SM, Thomopoulos TP, Kollia N, Jonsson M, Skalkidou A Correlates of postpartum depression in first time mothers without previous psychiatric contact. European Psychiatry. Eur Psychiatry. 2017;40:4-12. https://doi.org/10.1016/j. eurpsy.2016.07.003

PMid:27837672

2. Habel C, Feeley N, Hayton B, Bell L, Zelkowitz P. Causes of Women's postpartum depression symptoms: Men's and Women's perceptions. Midwifery. 2015;31(7):728-34. https:// doi.org/10.1016/j.midw.2015.03.007

PMid:25921442

3. Oktaputrining D, Susandi C, Suroso S. Post partum blues: The importance of social support and marital satisfaction in primiparous mothers. Psikodimensia. 2017;16(2):151-7.

4. Putriarsih R, Budihastuti UR, Murti B. Prevalence and determinants of postpartum depression in Sukoharjo district, Central Java. J Matern Child Health. 2018;3(1):395-408. https:// doi.org/10.26911/thejmch.2017.03.01.02

5. Sadock B, Sadock V. Kaplan and Sadock's Synopsis of Psychiatry-Behavioral Sciences/Clinical Psychiatry. $10^{\text {th }}$ ed Philadelphia, PA: Lippincott Williams and Wilkins; 2007. p. 857-69.

6. Ambarwati A. Postpartum Midwifery Care. Jakarta: Nuha Medika; 2010. 
7. Susanti P. Psychological factors affecting postpartum blues. Jurnal IImiah Psikologi. 2017;4(2):205-18.

8. Fatmawati DA. Risk factors that influence the incidence of postpartum blues. J Educ Health. 2015;5(2):94-101.

9. SDKI, Ministry of Health of the Republic of Indonesia. Data on Manpower and Labor force. Indonesian Demographic and Health Survey (IDHS) (Kementerian Kesehatan Republik Indonesia. Data Tenaga Kerja dan angkatan Kerja. Survei Demografi dan Kesehatan Indonesia (SDKI). Jakarta, Indonesia: Ministry of Health of the Republic of Indonesia; 2012.

10. Kurniasari D, Astuti YA. The relationship between the characteristics of the mother, the condition of the baby and the husband's social support with postpartum blues in mothers with CS delivery at the Ahmad Yani Metro General Hospital in 2014. Jurnal Kesehatan Holistik. 2015;9(3):115-25.

11. Zoleykha A, Mohammad A, Mohammad M. The importance of screening in prevention of postpartum depression. Iran J Public Health. 2021;50(5):1072-3. https://doi.org/10.18502/ijph. v50i5.6127

PMid:34183968

12. Meltzer-Brody S. New insights into perinatal depression: Pathogenesis and treatment during pregnancy and postpartum. Dialogues Clin Neurosci. 2011;13(1):89-100. https://doi. org/10.31887/DCNS.2011.13.1/smbrody PMid:21485749

13. Mathisen SE, Glavin K, Lien L, Lagerlov P. Prevalence and risk factors for postpartum depressive symptoms in Argentina: A cross-sectional study. Int J Womens Health. 2013;5:787-93. https://doi.org/10.2147//JWH.S51436 PMid:24294009

14. Yusuff AS, Tang L, Binns CW, Lee AH. Prevalence and risk factors for postnatal depression in Sabah, Malaysia: A cohort study. Women Birth. 2015;28(1):25-9. https://doi.org/10.1016/j. wombi.2014.11.002 PMid:25466643

15. Fairus M, Widiyanti S. The relationship between husband's support and the incidence of postpartum depression in postpartum mothers. Jurnal Kesehatan Metro Sai Wawai. 2014;7(1):11-8.

16. Mercier RJ, Garret J, Thorp J, Siega-Riz A. Pregnancy intention and postpartum depression: Secondary data analysis from a prospective cohort. BJOG. 2013;120(9):1116-22. https://doi. org/10.1111/1471-0528.12255

PMid:23651010

17. Nurbaeti I. Predicting factors of maternal depression during income family in Indonesia. Vol. 10. In: $1^{\text {st }}$ International Integrative Conference on Health, Life and Social Sciences (ICHLaS 2017), Alternative Press; 2017. p. 87-90.

18. Suryani EY. Postpartum blues; a literature review. Wellness Healthy Mag. 2020;2(2):298-304.

19. Apriliana KA, Maftuchah $M$, Nurhudhariani R. The relationship between education and parity with the incidence of unwanted pregnancy in family planning acceptors at PKBI as Sakinah Pemalang regency in 2014. SMART Jurnal Kebidanan. 2014;3(2):36-45.

20. Saptarini I, Suparmi S. Determinants of unwanted pregnancy in Indonesia (riskesdas 2013 secondary data analysis). Jurnal Kesehatan Reproduksi. 2016;7(1):15-24.

21. Intan K, Hendawati H. Risk factors for postpartum blues in Palembang city. J Kesehatan Poltekkes Palembang.
2019;14(2):2654-3427.

22. Salonen $A$, Kaunonen $M$, Astedt-Kurki $P$, Jarvenpaa $A L$, Isoaho $\mathrm{H}$, Tarkka M. Development of an internet-based intervention for parents infants. J Adv Nurs. 2008;64(1):60-72. https://doi.org/10.1111/j.1365-2648.2008.04759.x PMid: 18808593

23. Indriasari S. The level of depression in postpartum mothers at Morokrembangan Health Center Surabaya. Dunia Keperawatan. 2017;5(1):43-9.

24. Manurung S, Lestari TR, Suryati B, Mitadwiyana B, Karma A, Paulina K. The effectiveness of music therapy on the prevention of postpartum blues in primiparous mothers in the Midwifery Room of Cipto Mangunkusumo Hospital, Central Jakarta. Buletin Penelitian Sistem Kesehatan. 2011;14(1):17-23.

25. Wilkinson A. Anderson S. Wheeler SB. Screening for and treating postpartum depression and psychosis: A cost-effectiveness analysis. Matern Child Health J. 2017;21(4):903-14. https://doi. org/10.1007/s10995-016-2192-9

PMid:27832444

26. Hansotte E, Payne SI, Babich SM. Positive postpartum depression screening practices and subsequent mental health treatment for low-income women in Western countries: A systematic literature review. Public Health Rev. 2017;38:3. https://doi.org/10.1186/s40985-017-0050-y PMid:29450075

27. Anderson G, Maes M. Postpartum depression: Psychoneuroimmunological underpinnings and treatment. Neuropsychiatr Dis Treat. 2013;9:277-87. https://doi. org/10.2147/NDT.S25320

PMid:23459664

28. Yustisia IP, Izzatul A, Kusuma EW. Analysis of risk factors of depression symptoms in mothers in the postpartum period in Banjarsari district, Surakarta. Buletin Penelitian Kesehatan. 2020;48(2):131-8.

29. Indriyani D. Application of Concepts and Theory of Postpartum Maternity Nursing with Fetal Death. Yogyakarta: Ar-Ruzz Media; 2013.

30. Kusumastuti K, Astuti DP, Hendriyati S. The relationship between individual characteristics and postpartum depression in postpartum mothers at the Kebumen District General Hospital. Jurnal Involusi Kebidanan. 2015;5(9):1-17.

31. Shahry P, Kalhori SR, Esfandiyari A, Zamani-Alavijeh F. A comparative study of perceived social supportand selfefficacy among women with wanted and unwanted pregnancy. Int J Community Based Nurs Midwifery. 2016;4(2):176-85. PMid:27218115

32. Mariyatul Q. Overview of the factors (family support, knowledge, pregnancy status and type of delivery) behind the post partum blues incidence in postpartum mothers on the $7^{\text {th }}$ day (at polindes doa ibu gesikharjo and polindes teratai kradenan palang). Jurnal Kebidanan. 2018;10(2):9-19.

33. Yasi A. The Event of Maternity Blues Been Reviewed From Paritas Ibu Nifas in BPM Nanik Cholid Sidoarjo, International Health Conference; 2017.

34. Intan $\mathrm{K}$, Hendawati $\mathrm{H}$. Risk factors for postpartum blues in Palembang city. Jurnal Kesehatan. 2019;14(2):91-6.

35. Purwati $P$, Alfi N. Factors that cause postpartum blues. Jurnal Ilmiah Rekam Medis Informatika Kesehatan. 2020;10(2):1-4. 